Tobío, C., Gorfinkiel, M. D. New gendered relationships in spain: 'the other' in the care triangle. International Journal of Iberian Studies, V.20, N.1 (2007) pp. 41-63. 


\title{
The Work-Life Balance I - New gendered relationships in Spain: 'the other' in the care triangle
}

\section{Constanza Tobío and Magdalena Díaz Gorfinkiel}

\author{
Universidad Carlos III de Madrid
}

\begin{abstract}
Spanish couples have found new ways of organising their productive and reproductive lives within the domestic sphere. The increasing role of women in the labour market provides the basis for these new domestic structures, yet few social policies have been advanced to create greater compatibility between the worlds of work and home. Mothers of the new generation have to think of strategies to reconcile their labour and family life, with the employment of domestic service emerging as one of the most significant alternatives in recent years. On the other hand, immigration has suffered many changes, the most important being its increase and its feminisation. This is the result of the transformations experienced by the countries of origin of the migrants, including free-movers from the European Union, as well as the consequence of the creation of a new demand for workers in the receiver countries. Female employers and domestic employees meet each other in one 'home' - that of the working Spanish mother - now characterised by ethnic or cultural diversity and the permanent negotiation of individual, familial and group identities. The article analyses the discourse of working mothers who employ domestic service to care for their children, as well as the discourse of female migrant/immigrant domestic workers from Eastern Europe, North Africa and Latin America.
\end{abstract}

Paid domestic service had almost disappeared in Spain, and in other European countries, until the end of the twentieth century when the phenomenon experienced a revival due to the favourable market conditions resulting from a rising demand for domestic services and home help by working mothers, combined with an increasing supply of migrant women from developing countries. This rebirth of the phenomenon presents many differential characteristics compared with paid domestic work in previous decades, being the most obvious ones that it is more widely established and, therefore, involve a variety of social classes and situations. It occurs as a consequence of the connection between global processes and local solutions and it establishes new relationships between women where ethnic or cultural difference appears as a key feature. It is also directly linked to care of dependents and particularly of children. 
1 In the case of this article we only refer to children under twelve, leaving the situation of the elderly, disabled or sick for further research.

2 Commodification is the term used in the literature of care to refer to the transference of care activities to the market.

3 A. R. Hochschild defines 'global care chain' as the concept that connects women's work and care from a global scale.
Domestic service expands, basically, in those countries with few social policies designed to reconcile working life with the care of dependants. ${ }^{1}$ The first generation with a majority of Spanish working mothers has had to develop strategies to make their double responsibility in the labour market and in the family compatible, the main ones being kinship support and employment of domestic workers (Tobío 2001). There is a clear coincidence between the timing of immigration and the rapid increase in Spanish mothers' employment. Foreign domestic workers fill the gap left by an old social organisation where mothers were responsible for childcare.

The aim of this article is to analyse the discourse produced by two different groups of women in relation to each other: Spanish employers of domestic labour and non-Spanish migrants working as carers. It is important to observe the different aspects of their mutual perceptions based on a daily interaction, covering the type of relationships and knowledge they have of each other, the prejudices, stereotypes and expectations that arise, as well as the level of different cultural patterns and behaviours. It is argued here that migrant workers produce a new interaction in Spanish homes, one based on mutual need between employers and the domestic workers. Because of the migrant origin of most of the domestic workers, multi-culturality enters the home and gets reflected in different lifestyles, habits and approaches to care. This article also raises the related issue of the involvement of men in childcare. The empirical evidence from our research suggests that the presence of a so-called surrogate mother, in this case the migrant worker, tends to leave men out of care responsibilities, thus reproducing an old division of work where gendered roles remain very much the same, even though the actual woman who takes on them is no longer the real mother.

The analysis focuses on women because they are still responsible for most of the care work, and consequently, it is among them that the rules and habits around it are being transformed. The basic underlying tension in the continuous negotiation of identities (Momsen 1999) among these women is the antagonism between the position of employer and employee or, in other words, their labour relations. This has generated new issues, as the transfer of care responsibilities is no longer related to social class (dominant/subordinate) as it was in the past, but instead provides the opportunity for the women employers to gain access to employment and public life. Thus, the intertwining of private and the public becomes more complex, as on the one hand, the home is a workplace for the paid carer, whereas the commodification ${ }^{2}$ of care is the condition for it being de-familiarised, from the mother-employer perspective (Esping Andersen 1990, 1999; Hobson, Lewis and Siim 2002). The relationship between working mothers and domestic employees is defined by the caring for the children, but this role is in practice shared by both women. Furthermore it creates 'global care chains' (Hochschild 2000) ${ }^{3}$ as paid carers are often mothers themselves. Thus, there is a process of substitution and delegation of care 
work that links women and children from distant places in the world; in the case of our research, Madrid family homes became linked with households from Ecuador, Colombia, Morocco, Poland or Romania, among other countries. In addition, it is argued here that the nature of these global relationships is asymmetrical and reproduces aspects of the dialectic of the other analysed by Simone de Beauvoir in The Second Sex (1999). If the Hegelian male slave recognises himself in the conscience of the master, and a woman in that of a man, then in the relationship between working mothers and migrants - substitute mothers who assume domestic and care responsibilities - we can see an unequal relation at the level of identity. The migrants are 'the others', not only as a result of their different origins, but also because they are the replicas, as similar as they can be, of the real mothers who seek - voluntarily or not - to acquire new roles as economic providers without abandoning their maternal role. In the context of globalisation, between the dualities of private/public and sameness/difference, new gendered relationships emerge around the issue of care. To what extent they challenge or reproduce women's subordination is not known at this stage. As Gregorio Gil (1998) points out, the analysis should take into consideration both ideological issues, understood as the fundamental perceptions of gender relations, and everyday activities.

The article will be structured in five sections. The first part aims to frame the article and it refers to the social context and transformations in Spain. The second section relates to the consideration of domestic service from the perspective of the employers and the employees: As a job and as a resource. The third concentrates on the perceptions and discourses women elaborate of each other, while the fourth focuses on the relationships women build around the activity of care. The last section analyses the gender implications of the existence of domestic service. The conclusion raises some interesting concerns about these relationships and meaning of domestic service for women, the family and the whole of society. The appendix contains the main methodological characteristics of the research.

\section{Spain and its social transformations}

The transition to the dual-earner and adult-worker family model (Lewis 2001) took place late in Spain, compared with other European countries, but caught up rapidly during the 1990s. It is important to bear in mind that Spain had a very particular socio-political history that enforced a strong patriarchal model, which only began to be challenged in the 1970s. Data of women's employment rates show the important change going on in the labour market structure, showing that the clear gender separation between the public and the domestic spheres has diminished (Table 1).

It can also be added that Eurostat data show that in 2005 in a majority of cases ( 53 per cent) both members of couples aged 20-49 are employed, usually in full-time jobs (Eurostat 2005a), a statistic that also reflects the 

as Leonor Kofman and Annie Phizacklea (2000) maintain that this pattern was not as clear as Bohning states, as many women were already entering Europe as active agents in the 70 s.

\begin{tabular}{lll}
\hline II 1986 & II 1996 & II 2006 \\
\hline $28.83 \%$ & $37.97 \%$ & $47.93 \%$ \\
\hline
\end{tabular}

Table 1: Women's activity rates.

Instituto Nacional de Estadísticas - INE.

II $T=$ second trimester.

fact that women are staying in the labour market after having children. This re-organization of the sexual division of labour has made it obvious that the current regulation of time in society no longer fits with new structures and new social priorities. Women are not any longer fully available for activities related to care and reproduction and, therefore, there is a need to delegate these kinds of activities. The Spanish State has not yet confronted this new reality with relevant solutions. The investment in family policies is small, and as the directed to help families to reconcile personal and working life is small, and as the data illustrates, constitute only 0.5 per cent of the GDP through the period 1996-2002 (Eurostat 2005b).

As a consequence of the lack of public solutions, domestic service becomes a vital resource allowing family and working life to be compatible. Foreign women constitute the main domestic workers as immigration has risen sharply in Spain, and the native population is not willing to engage in this kind of job. Figures on migrant workers, and particularly on those working in domestic service, are subject to debate as it is very difficult to track this phenomenon. Anderson (1997: 38) has estimated 600 thousand domestic workers in 1997, a figure that would include those of Spanish origin. Nevertheless, figures for Social Security registrations show smaller numbers. In 2005 there were 253.770 foreign contributors to the household employee system representing 69.6 per cent of the total persons registered with the system. (Seguridad Social 2006). It is important to bear in mind that this includes neither those who do not have a residence permit nor those who work in the black market.

\section{Domestic service as a job and as a resource for childcare}

Both working mothers and migrant domestic workers have a strong orientation towards the labour market and they meet, precisely, because of this desire or need to engage in paid work. The demand for domestic help can be explained by the increasing participation of Spanish women in employment and the insufficient public services devoted to their dependants, while the increase in the supply of domestic help can be related to the increase in emigration from developing countries. Even though Bohning (1984) explained in his influential migration model that the initiative in the migration process is usually taken by men, with women following as wives thanks to family re-unification policies once men have reached certain stability, the reality no longer seems to follow this pattern. ${ }^{4}$ Migratory processes include many different situations and causes, but it is common nowadays to find a large number of women 
taking the initiative of emigrating for work purposes, largely due to the economic restructuring processes of their countries of origin, which had strong negative effects on employment, as different authors have pointed out (Anderson 1997, 2000; Ehrenreich and Hochschild 2003; Parreñas 2003). This seems to be the case of the important female migration to Spanish cities, like Madrid or Barcelona, where employment opportunities are considerable.

Spanish working mothers, on the other hand, are also generational pioneers as they are the first generation of Spanish women to mostly remain in paid work while having children. It is true that their involvement in the labour market has been late relative to other European countries, but it has been a rapid and strong shift. Hence, they are facing difficulties in making their jobs compatible with their care responsibilities. They mostly develop strategies of an informal and private nature to deal with the practical problems arising out of the processes of social change in which they are involved. Paid domestic help is one of the main resources for those who can afford it. Data from the Survey on Family-Employment Reconciliation $^{5}$ (Encuesta sobre Conciliación Familiar y Empleo - ECFE) (Tobío 1998: 178-191) show that 28 per cent of working mothers make use of some kind of paid domestic help, even if most of it is on a part-time basis (only 6 per cent have full time aid and 2 per cent have live-in help).

Apart from the tendency towards involvement in paid work and the innovative nature of the solutions to the care of dependants, there are few similarities between the two groups of women - rather, stark differences. In the first place, social and cultural habits differ, and often does the language, even in the case of Latin American immigrants. Secondly, and more importantly, the structurally different positions as buyers and sellers of labour power potentially oppose them in terms of interests and perceptions. For Spanish working mothers, the employment of paid domestic workers is, in practice, more complex than the use of any other service acquired on the market because, even if they buy help like a commodity, its content and shape follows a very strong family logic. In fact, it fits and sustains the current, still traditional, Parsonian family model. ${ }^{6}$ It can be argued that the commodification of domestic help allows the family to remain unchanged, keeping women at the centre of the household and fully dedicated to it. Domestic workers complement or substitute mothers in the role that the gendered division of work attributes to them and compensates for their 'abandonment' of the family, an idea that often underlies working mothers' discourse. This explains why the research found that they look for maternal substitutes as similar to themselves as possible and reject those who are different, ultimately making those domestics who seem closer to Spaniards the most valued:

Instead of taking them to bed and praying to the Holy Father, she talked to them about her religion. Very strange, very bizarre, she gave them such talks about Mohammed . . . (1)
The Survey of FamilyEmployment

Reconciliation (ECFE) includes 1,200 interviews representative of Spanish working mothers with a sample error of 3 per cen for a confidence level of 95 per cent.

6 Parsons (1902-1979) defined the family as a group formed by a woman, a man and children, meaning a classical heterosexual nuclear family with clear public/private gender division of roles.

$7 \quad 1$ = Discussion group of upper-middle class Spanish working mothers, 2 = lowermiddle class Spanish working mothers, 3 = Latin American domestic workers, 4 = Eastern European domestic workers, $5=$ North African domestic workers. 
She seems to be Spanish, she's been here for very long and has the same habits. She does what I say, how I say it, in short, she tries to be nice to the family, she does everything how we do it and, yes, she's adapting very well, I could even say she looks like a Spaniard. (1)

Considerable differences between upper and lower class employers were found over the meaning of domestic workers and the role they play in the care mix. For the former, paid help provides them with quality of life as they can rely on it for the daily family duties. For the lower-class employer, hiring domestic help is a sheer necessity, as they have no other care resource to rely on, and can only afford part-time help for a few carefully calculated hours to fill gaps between home, work and school. Upper-middle class women were able to draw on several different ways of taking care of their children, domestic help being only one of them. Grandparents contribute with emotional support and family roles and also with the control of the caregivers when parents are not at home, while on the other hand crèches give children the chance of socializing with their peers. Domestic workers, therefore, give continuity of care and stability through their presence.

... I think that's not good for them [the children] to stay with the grandparents the whole day, neither in the crèche nor with the maid, they have to have a little of everything. (1)

It's an obligation, tell me what can you do (. . .) In my case my parents live abroad and I have no [other] relatives, so I have to take it or leave it. I leave my job or I hire domestic help. (2)

When envisaging the future, both upper- and lower middle class employers' discourses were found to differ. The former thought that the current reality would persist as it was very difficult to imagine an end to poverty, which would stop migration from being necessary: "While there's poverty there will always be migrations." (1) was said explicitly. Hence, they consider they will be able to continue counting on domestic workers to help them to make their working and family lives compatible for the next few years or even decades. In contrast, the discourse of lower-middle class Spanish working mothers was hesitant about the possibilities of depending on migrant domestic help in the future. They tended to think that migrants will progressively integrate into Spanish society and will be in a position to do other kinds of work - 'like ours' - or to ask for higher salaries for childcare - just like the few Spaniards who are still working in this kind of job. The main gap between the two groups of Spanish employers has to do with how well-off they are, as the upper-middle class mothers can afford to pay much more for the same service while the lower-middle employers know that their constrained finances allow them to profit only in this very exceptional situation, which they think is bound to come to an end. Then they would have to find another solution, probably by turning to the public sector. 
The study found that the perception migrant workers have of domestic service is also ambiguous and complex. They tend to consider their job as transitional, until the new country allows them to obtain other kinds of jobs more closely related to their studies or previous work experience. Care and domestic work are the only occupations that are fully open to them excepting perhaps agricultural labour - as few Spanish women want to engage in this kind of work any longer. Though there are different ways of working in the domestic sphere, migrant workers are normally offered the live-in positions. ${ }^{8}$ They often consider this a good option for the first months after arrival as it helps them to learn the language (those who need it), have somewhere to live and to feel secure in an environment that is still strange for them. But other migrant caregivers believe it is too hard to work as a live-in because of the almost unlimited hours of work, and lack of freedom or privacy. Some of them even define it as a 'prison for women'.

I see domestic work as a prison for women, you have to stay in the whole day, you wake up in the morning and do what you already have done yesterday (. . .) you do things you haven't done in your life, for example, you have to clean the windows every day, you have to cook, to clean the toilets, clean the whole house, take care of the children ... (5)

-In the building where I live there are many foreigners taking care of children and old people, they're all foreigners. There is not one Spaniard taking care of children or an elderly person, at least not where I live.

-Yes, it's a job almost nobody wants." (3)

Despite these attitudes, the reality is that in many cases domestic work becomes a permanent situation. The hope of switching to another job gets lost, though many women do find better positions within the field of domestic work itself, moving to a live-out job or working on an hourly basis. ${ }^{9}$ In fact in many cases the whole migration process, planned as a temporary experience to save money and then return to the country of origin, becomes a stable situation from which it turns out to be impossible to escape. Some workers mention that there is a point when even the will to move on, or go back, disappears.

\section{Exchanged gazes: Perceptions and stereotypes between women}

The analysis of the discussion groups discovered that the women employers perceived the lives of migrant workers as hard and difficult, mainly because they were so far from their families and had so little money to live on. Nevertheless, they consider that the migration experience is good for these women because it allows them to improve their standard of living compared with that of their country of origin. Upper-middle class employers, more than lower-middle class employers, were ambivalent towards these issues and towards migrants' workers in general, as they mixed ideas of respect and concern with paternalistic notions of cultural and intellectual
8 The Research Group Ioé estimates that between 55 and 80 per cent of immigrant domestic workers start as live-in (Colectivo Ioé 2001: 294).

9 Colectivo Ioé (2001: 751) gives some figures for some specific national groups: 60.3 per cent of the Moroccan women interviewed in their study started as live-in while in 2000 only 30.2 per cent remained in this category. For the case of the Peruvians, the numbers are 65.1 per cent vs. 43.8 percent and for Ecuadorians 79.7 per cent vs. 60.2 per cent. 
superiority. Interestingly, the social differences between these two groups of women were found not to be the only explanation for their attitudes. The type of domestic service they have - live-in, live-out or part time - was also a factor. In fact, power relationships were found to be more complex in a household with a live-in worker. The lower-middle class employers expressed only one specific complaint about migrant workers, namely that they were slower than Spanish domestic workers. They also talked of rumours about them stealing small amounts of food and other items, even though they admitted it had never happened to them and was not specific to one nationality but was the result of having opened their house to a 'stranger'.

Both groups of women employers labelled migrant women with stereotypes, making sweeping statements about different cultural groups. The main group that was attributed pre-established-stereotypical-features was the North African, whose nationals were considered to belong to a culture that was 'too distant' and even 'problematic'. It was striking to find that every single employer mentioned that they had never employed a NorthAfrican domestic or nanny due to a conscious decision to avoid them. They perceived them as following traditions that were too far apart from the Spanish way of life and where religion - a different one - played an essential role. The discrimination that their daughters might suffer seemed to be one of the key reasons for their rejection of Arabs as child carers.

They are almost unknown in domestic service [North Africans] and look, I think it would be the only place I would have problems with, mostly for child care, because it's an upbringing so extremely opposed [to ours] and I disagree so much with that, I think it would be bad for us. I mean I would be afraid, I'm not talking about the cleaning, but to be with the children, even half an hour a day. To think - I have a daughter and a son - I don't know, I'm just thinking, that she could favour my son just because he is a boy ..... (2)

Lower-middle class employers differentiated between the acceptability of North Africans for childcare - clearly seen as non-desirable - and other types of domestic tasks such as cleaning, which was seen as less of a problem. Latin American workers, on the other hand, were very much appreciated as caregivers. They were considered to be very loving and patient, and there was the fact that the shared language made communication easier. Nevertheless, upper middle-class women said they did not appreciate them much as cleaners as they were too slow and not used to the materials and appliances common in Spain. Dominican women, in particular, were considered to be too 'familiar' with the opposite sex.

... but you also have the problem that if she's South American you don't like her character, they're very slow, they don't clean well, they're not used to our domestic appliances like the Europeans ... (1) 
Eastern European women, on the other hand, were much valued for their discipline and efficiency, but found to be too distant and even harsh with the children. The lower-middle class employers also referred to the fact that in many cases the latter group was very well educated, even to a higher level than they themselves, making the hierarchical power relations more difficult to establish.

Turning now to the findings for the three groups of migrant women, these were also rich in examples of stereotyping or pre-conceptions. They had quite fixed ideas about how the host society saw them as workers, and also indirectly as women of other societies. Eastern European workers considered themselves as highly educated people, more than the rest of the migrant groups and even more than their own employers: "I tell you that the truth is that I'm smarter than her [the employer]. (. . .) There are some people I'm working for that have less education than me but what can I do? . . ." (4). They believe they are the most sought after domestic workers: "Yes, I've been told by many people that they prefer the Polish and Rumanian ones." (4) even though the language barrier can constitute a problem in the early stages. This would explain why Latin Americans have it easier when looking for work. Paradoxically, North African immigrants saw themselves as the ideal people for childcare work, as it requires a high degree of trust, which they felt they could offer because of their Muslim background. They nevertheless suspected they were less desirable than women from other countries, mostly Latin American ones, because of their initial lack of knowledge of Spanish and because of the different habits and way of life in Spain and Arab countries, particularly regarding food: "That's why I tell you they prefer workers from countries where they speak Spanish, South Americans, yes, from Ecuador.” (5). As to the Latin American group, the women took for granted that the employers preferred them because of their common language, and saw themselves as highly desirable workers.

As to the treatment meted out because of their status as migrants not just workers - by the employers and Spanish society at large, the Latin American group was found to have the more elaborate discourse. Differences regarding how social relationships were organized were repeatedly mentioned, with women emphasizing the formalities and regulation of relations in Spain, as well as the distance set in their interaction with neighbours. The Latin American women saw themselves as behaving differently from the average Spaniard, a fact they consider is perceived and made constantly clear by the host society. They portrayed themselves as being sweetnatured, and expressing a calmness and serenity when confronted with difficult situations. Most of them admitted they had become colder and more distant, more like Spaniards, in order to avoid misunderstandings towards them. Even when they recognised that they are labelling themselves as a group, they tended to complain about the tendency of Spanish society to view migrants as a homogenous group with similar behaviour patterns that mask or even deny the right to have an individual identity. 
Spanish people should think differently about us. We are immigrants, but we are not all the same. We have different ways of life. Of course, some let us down, people from our countries, just as here there are thieves too, as in my country. But we are not all the same. (3)

... look, we're very open and loving, very sweet, very friendly, for example [at home] in a block everybody knows each other and here I don't know the person who lives next to me (. . .) and I don't know why here if you call someone 'my love' or something like that, [just as a way of talking] when you say 'my love' they feel like you're saying something else . . . (3)

By contrast, the group of women from Eastern European countries did not perceive any remarkable difference in their temperament and that of Spanish people and, therefore, their discourse developed around the idea that characteristics are individual, rather than social. They did mention, as Latin Americans do, the looser family ties in Spain compared with their own countries. North African migrants likewise failed to mention a series of differences, but just as the Latin American group did, they consider that in Spain relations with neighbours, friends and family are much colder than in their country of origin. Nevertheless, they did address the negative image they feel they have in Spanish society where, they say, people automatically connect the presence of Arabs with 'problems': "I'm very sorry to say this but everybody, here in Spain, even other migrants, they always say it is only Moroccans. Who steals? Moroccans. Who does this? Moroccans. All bad things are thought to be done by Moroccans." (5). Part of the discrimination is based, they believe, on local ignorance of their societies and culture. Some discriminatory situations, even though less frequently, were also mentioned by Latin Americans that also felt rejected for their different ways of interacting, for being identified as part of a problematic community, or for the simple fact of having different physical features.

In short, there were some quite notable differences in how the different groups of migrants think they are perceived by Spanish society, both as workers and as citizens. The negative pole is represented by the North Africans, most of them from Morocco, who says that they tend to be seen as culturally too distant to be domestic workers and particularly child carers, as well as being collectively suspected of anti-social behaviour. At the other end of the scale, Latin Americans think they are highly valued as domestic workers, but that social integration in general is not so obvious, whereas Eastern Europeans find there are generally no relevant differences, but paradoxically, as domestic workers they are not the most sought after.

\section{The mother and the other: A relationship around care Typologies of relations}

The social relations originating in the sphere of paid domestic work have specific characteristics that are not present in any other social interaction. The main specificity is that the relationship develops in a space - the house of the employer - that is not neutral, and requires a continuous negotiation around 
privacy and familiarity. Moreover the practical and physical tasks that these women share - organizing, cleaning and taking care of the house - are aspects of everyday intimate life that are often difficult to negotiate. Communication around these issues between employers and workers is often tinged with distrust and even suspicion, probably related to the permanent ambivalence of a home that is a workplace and a workplace that is a home. The opposite situation described by Hoschchild (1997) is when working parents flee from their homes - that are no longer havens - to their offices, which become a kind of surrogate home - and this arguably becomes much more complicated in the case of domestic service. The employers' home is a space of paid work for the domestic worker, but the fact that it is somebody else's home makes it a workplace that is quite different to any other. Inevitably the workers are - and they are aware of it - 'strangers' with all such label means. The risk of intruding is high and requires a great deal of tact. Linguistic and cultural differences add to the risk of misunderstanding. This is why in some countries, policies are being developed to help migrants get acquainted with how Western homes are run and what might be expected of them (Ehrenreich and Hochschild 2003: 7; Scrinzi 2004). There are no similar measures to train employers to learn something about their employees' background and the analysis of the discourses of this study found no evidence that employers try to find out as a matter of course once the carer has arrived. It was taken for granted that it is for the foreigners to make the effort. Thus, a deep asymmetrical power relationship between workers and employers is revealed. And, as we will argue in the following pages, the home as a workplace, specially when the care of children is concerned, makes domestic service a much more complex issue than a pure labour market relationship.

There are four different types of relations between employers and employees that can be distinguished through this study. 'Ideal types' do not exist as such in real life but help us disentangle the variation identified through empirical observation. ${ }^{10}$ Two of them look back to the past - the paternalistic and the servile relationships - whereas the other two correspond to modern times - the professional and the cooperative. The four types can also be classified according to a distance-proximity axis, in which the paternalistic and cooperative models imply a closer relationship between employer and employee, and the servile and professional relationships indicate a larger distance, as shown in Table 2.

The medieval servant classes are the forerunners of current domestic workers. But categories differentiating between private and public, family and employment, work and training did not exist in the same way in medieval times, as servants were personally dependent on their masters or

\begin{tabular}{lcc}
\hline & Past & Present \\
\hline Distance & Servile & Professional \\
Closeness & Paternalistic & Cooperative \\
\hline
\end{tabular}

Table 2: Employer-employee relationship typologies in domestic service.
10 'Ideal type' is a category coined by sociologist Max Weber (1864-1920) to be able to explain and organize reality. It is a methodological construction that allows empirical questions to be analyzed, as reality does not follow an 'ideal'. 
11 Lan (2003) on the other hand analyzes the strategies that employees have to profit from paternalistic relations. mistresses and the actual content of their work was whatever they were asked to do. At the same time they were protected and trained by them (Ariès 1973: 252-258). During the Franco fascist dictatorship in Spain service developed as a deeply gendered issue as the feminine ideal promoted was that of a 'servant' of husbands, parents, children or country (Otero 1999: 1991). Despite, or perhaps because of this, the association of paid domestic work with 'servants' was explicitly rejected both by employers and employees in our research. They only refer to servants in the context of extreme cases of mistreatment: "But it depends on the families, there are Spanish families that think that you are a servant, not a person ..." (5).

The paternalistic model is based on the idea that the domestic worker one way or another is 'part of the family'. The status of domestic employees in families is a widely debated issue in the discussion groups and in the literature (Anderson 2000; Parreñas 2001; Hondagneu-Sotelo 2003; Lan 2003). In the paternalistic type of relationship the domestic is more than just somebody who does a job for a salary. In the discourse of the women, a difference was made between 'being part of the family' and being 'in the family' or 'living in the family" in the context of the many hours they spend in their employers' homes, specially if they are live-in workers. The 'quasi-familiar' treatment this relationship generates has many different meanings, for it can include notions of trust, proximity, responsibility or the consideration of feeling at home.

The truth is that they treat me very well; they treat me as if I were their daughter or somebody from their family. (4)

Yes, I consider myself [part of the family] (. . .) With the woman I work for now, we all eat together at the table, we eat together at the table, the lady told me when I started 'Alex, you're not going to wear uniform because I'm not interested in the neighbours knowing I have a housekeeper, you come and bring the clothes you want'. Here they treat me as one of the family. (3)

This familiar relationship does not, however, prevent tensions from arising in relation to the wages, hours worked, or Social Security payments. There is ongoing uncertainty on the part of the care workers, even though not expressed in a very explicit way, about the benefits that these paternalistic relations can bring to the employers. The employees are aware that this quasi-familiar relation prevents them from fighting for improved working conditions and tries to make them forget that it is a job, like any other, done for money. ${ }^{11}$

They are very careful, they always give you presents, they always take you everywhere, but that's not all, because what you need is money to be able to live. (3)

In the 'professional' kind of relationship, domestic work is an occupation just like any other; therefore, formal business relations are established. The 
discourse around this kind of relationship was mainly developed by uppermiddle class employers, but was not prevalent even among them. The issue here is that the supposedly professional relationship ("just like any other job') would in fact require very different working conditions that few employers would be willing to accept as the regularisation of the work should be much tighter and the conditions related to wages, holidays or hours of work far clearer: '. . . I think she's a worker, and based on that I have to respect her and help her and she has to comply with the requirements of her job willingly, that's all'. (1)

Turning now to the kind of relationship we have labelled 'cooperative', notions around this type of relationship developed mainly over the issue of childcare in the lower middle-class employers' group. Cooperation is how the link between the real mother and the 'surrogate' or substitute mother was perceived. Cooperation between women appears also as a way of mitigating the hierarchical components in the relationship, which tend to be rejected by lower middle-class working mothers. The idea of these women is that they only have a person at home to help them with specific tasks when they are also working for others, so at the end they are both doing a service outside the house to be able to have a better life with their own families:

I don't see her [the domestic worker] like a person under my service, I see it more as we help each other, she helps me because I pay her for working some hours and in other things I help her, so, we help each other, so maybe for me the relation is different. . . (2).

As to the distance/closeness axis, the long hours some women spend in the same house creates a proximity that can be consciously broken by use of several 'markers' that remind both women of the different position each of them are supposed to have in the relationship. The main way to deploy these reminders is through the use of the language, for instance, using the formal 'you' 12 as a marker of distance : 'If you don't use the formal "you", all respect gets lost.' (1). This question was not commented on by the lower-middle class group, partly because not much time is spent together and therefore not much need to set a distance, and partly because the cooperative model and ideology is dominant: 'I address her using the informal "you", and so does she, but we are together 10 minutes or so (. . .) I go to work, she leaves the boy at school and then she leaves ...' (2)

\section{Ideas and ideals of mothering}

In child care work, as can be seen, the settled relationships are very complex and embody the notion of mother that the two women share. In many cases mothering is a responsibility transferred to the paid carer, who is expected not just to be a worker but also a mother, or a second, substitute mother, who will care for the children in both meanings of the word. Discourses suggest that there is a clear expectation of personal involvement 
of carers with the children: Loving the children they care for is part of their job. It is even expected that bonds with the children and the family will remain after they quit the job. If they do not, it is often said that domestic workers are ungrateful.

When children are involved, feelings should appear. I had a nanny when my children were born who took care of them for the first two years, she was the one who fed them every day after the fourth month [when the mother who speaks went back to work]. It hurt me a lot, it really did hurt me that when she left, she never returned to see the children. (1)

Domestic workers are 'doubles' (Anderson, 2000: 16) - substitutes, replicas of mothers. The most precious beings - children - are handed over to them and they are expected to perform correctly. Beyond being paid carers with specific tasks to do, they are expected to be mothers to the children and for such feelings to be aroused spontaneously through interaction with the children. In fact they often are. This does not mean they are paid to be mothers - the idea of being paid to be a mother seems to be particularly embarrassing for the employers - but it has to do with the association between women and motherhood. In post-industrial societies all women are supposed to be mothers, thus capable of developing maternal bonds with children. An interesting theoretical debate arises here in relation to whether it is love, or merely care that parents 'buy in' through paid domestic help. Hochschild posits that both love and care can be conceptualised as the 'new gold' that the First World is once more extracting from the Third World, just like natural resources or a cheap labour force (Hochschild 2003). The consequences of this new form of unequal exchange, Hochschild claims, are suffered by migrant mothers and by the children of migrant mothers who stay in distant countries at the other end of the global care chain. On the other hand, children from the core countries multiply their mothers, and thus receive even more love and affection, both from the biological mother and from her substitutes.

Migrant domestic workers are supposed to be a part of 'us' in their feelings and behaviours but at the same time are considered 'the other' because they are different, speak differently and come from different cultures. Migrants constitute 'others' in the double - and contradictory - meaning of being different and similar. In both cases, what is absent is their real identity. They can be part of the family or mothers to the children of the family, but not have their own concerns, problems, worries or joys. In an interesting novel about the traditional Madrid upper class, Manuel Longares (2001) tells the story of a nanny who worked for more than forty years in a family. When she retires, they want to give her a nice present but they suddenly realise that they do not have the slightest idea about what she might like. They finally decide to give her a photograph of the whole family in a silver frame, making it clear that even though she is not one of them, when she becomes old and leaves, the only identity they recognise in her relates to themselves. 


\section{Gender implications of paid domestic work}

The involvement of men in domestic work, particularly in childcare, is slowly progressing all over Europe (Malpas 1993, 1999; BarrèreMaurisson 2003; Bjornberg 1996), but the underlying logic of different cases seems to respond to different patterns. In some cases, like in the Nordic countries, it is directly related to social policies that seek to make family responsibilities and employment compatible from a gender equality perspective. Paternity leave for childcare under the 'use it or lose it' principle represent a good example of how men are being 'gently pushed', with considerable success, to see themselves as carers (Leira 1992, 2002). Yet research by Gregory and Windebank (2000) shows surprisingly that the involvement of men in care and domestic tasks might be lower in France than in Britain in spite of more generous social policies in the former country. Childcare policies, if not associated with gender equality, can delay men's direct participation in domestic work and care as these can be off-loaded onto other resources and men's presence is then not perceived to be 'necessary'. The United Kingdom represents an opposite case, as men in this country, Gregory and Windebank argue, are much more active than in France precisely because the lack of childcare facilities or any other kind of resources makes their work in the home indispensable, especially if both parents work full-time. In Spain, the lack of policies does not push men into care responsibilities but rather leads to informal solutions based on kinship support - the maternal grandmother being the key actor or to paid domestic work and this seems to be delaying the involvement of men in the home.

As mentioned above, evidence from our research shows that gender relationships in the employers' households follow a very traditional model and have not experienced great changes in recent years, even though all the women are employed, most of them full-time. The male breadwinner model still appears as hegemonic among Spanish families. Generally extended to all employers is the idea that paid domestic service is a condition for them to be able to stay in the labour market. They all accept that men are the ones who 'have' to work, thus getting out of domestic responsibilities, and women the ones who can choose to engage or not in employment life. Therefore, the cost of having domestic service gets calculated on the basis of the woman's salary as they are the ones whose absences leave a gap in the household that has to be covered by somebody else.

-. . . then, if you work you have to put somebody in the house and if you don't, you do what that person does, but husbands, no, I don't know, it's like they are the ones who have to work.

-You work, so what do you do with the children? When you start counting how much it costs for you to put a foot out of the house, to buy in another, to have housekeepers and I don't know what else . . you say ok, I put in this much and it will cost me that much - it's the feeling that because I work there are many outgoings. (2) 
The involvement of their husbands in household tasks was found to be very small. In spite of that, the women did not argue directly for a reorganization of work with their partners, but instead called for changes to be made by other social agents, such as companies or schools. Men were not perceived by them to be directly concerned, as the home infrastructure is supposed to be taken care of by paid domestic workers. Instead, demands for more balanced gender relations are targeted by the two groups of working mothers participating in the study. They maintain that society should automatically stop valuing men more than women in their capacity for work and employment. The greater stability, promotion prospects and higher salaries found in male employment lead many women to focus to a much larger degree on household issues and they are ultimately in an inferior position in the labour structure. Both groups of employers agree on this, although those from the lower middle-class insisted more as it is more common for them to have to sacrifice their jobs because of their more limited employment opportunities. Paid domestic service therefore becomes the main way to make family and employment compatible without interfering in the professional lives of husbands. Again, it was the group of lower-middle class women who expressed this situation most clearly, describing how domestic workers substitute them only when their jobs prevent them from looking after their children. Meanwhile upper-middle class women described domestic service as a resource that made their lives less stressful and improved family and couple relationships by allowing them to be more relaxed when their husbands came back from work.

And it helps the marriage because you arrive home tired from work, start bathing the children, fight over their supper, prepare the dinner for him [the husband]; in the other way [if you have domestic help], you bath the children if you want, and make supper for them if you want to. I usually do, but if I don't feel like doing it one day, I don't, and then when your husband arrives, he finds you as fresh as a daisy instead of exhausted . . . (1)

Another aspect of men's de-involvement in the household is that women from both groups realized that the relationships with domestic workers are maintained almost exclusively by them, and so the logistics and management of the house ultimately remain in their hands. They took on board the fact that in many cases, men have very little to do with maids or nannies and know virtually nothing about them. Some remarked, and even stressed, that it was thanks to the presence of domestic help that they can go on, or return to, ignoring many household issues. Women's husbands and partners seemed to be quite willing to accept the expense of paid help, but tended to consider that this means they were free from domestic responsibility: 'If I ask my husband for help he tells me to have the maid for more hours, he prefers her to be here longer. He will not take a glass to the kitchen, that is what he answers.' (1). 
The difficulties of combining family and professional life, as well as the sacrifices and efforts it involved were largely commented on by the employer mothers: 'For me everything is hard because when I am at work I am thinking about my children. When they were small, you know. . . one is sick, the other . . . then the nanny doesn't come, this, that and the other . . . so many problems that you find it difficult to concentrate at work. And then when you're with your children you are also thinking about problems you have at work and you don't pay them the attention they deserve...' (1). Some lower-middle class women even compared their own situation to that of domestic workers, but ultimately concluded they had it easier because on top of paid carers they could often rely on family networks as well.

Yet another aspect of gendered relationships in the household emerged in discussions with the upper-middle class employers. They mentioned that domestic workers, or nannies, can be a threat or a potential temptation for husbands. Traditional patriarchal practices emerged in well-off modern households as fears or fantasies. This contradicts the notion of the invisibility or inexistence of domestic workers as far as men are concerned. Though none ever mentioned that it had happened to them, it was said to happen. Half earnestly, half joking, interviewees advised each other to prevent it: 'To start with I would never hire a gorgeous girl to work in my house, why should I suffer? I just avoid the potential problem' (1). Interestingly, this issue was not mentioned by lower-middle class working mothers. One explanation would be that when paid help is part-time, the problem is much less likely to occur.

On the other hand, migrant domestic workers also revealed the unbalanced gender relations of their own households, where daily tasks are not shared equally between the couple. The three groups of migrant women said that they were responsible for the planning and organization of household duties and admitted that the large amount of single-handed responsibility, together with their paid work commitments made them feel exhausted. Their complaints about this were toned down as they saw it was impossible to run away from their responsibilities. The experience of migration had taught them that this was the reality for women all over the world. These three groups considered that in Spain the majority of the domestic responsibilities also fell on the shoulders of women, as the relationships they established in the houses they worked in were almost exclusively with the women of the household.

Everything is hard, nothing in life is easy, in my country, in yours or in Japan, everything is extremely hard for women of all countries, whether they are Spanish or whatever, it's very hard, life for women is very hard (3)

I work eleven hours and a half, I arrive at nine, [then] get home to feed all my family, to bathe them, by twelve at night I'm sleeping, then I wake up at half past five to be able to prepare the food for my husband to take to his work ... (4) 
Despite the numerous similarities with the situation of Spanish women identified by the three migrant groups, the Latino group mentioned a very relevant difference, namely that related to the use of public space in their new social context. They believed that women in Madrid were able to join many social activities and could use 'the street' to establish social networks, even independently of their husbands or partners. The Latin Americans therefore decided to start using city spaces for themselves as men do, without feeling any guilt. They knew, however, that this greater degree of freedom in the social sphere did not lead automatically to a better situation for women in the private sphere.

The Spanish women are more independent, it's more common for them to go with their friends for a walk and even sometimes I heard that the husbands stay home; it's another way of thinking, we don't - maybe there's more freedom for women in this sense, they have more independence to go out, to make it, to make a life, but the obstacle is that I think the duties of the house are always there for women, there hasn't been a change despite everything (3)

The issue of the changing - or unchanging - role of men in the house as a consequence of migration sparked much debate, with many of the women arguing that a progressive change towards greater gender equality was being experienced. The group of Latin American women extensively developed the idea of not being so docile and obedient towards men as they used to be, and as women generally were in their own countries. The North African women attached greater importance to this issue and spent a long time drawing comparisons between Arab and Spanish men. Some of these women considered that the behaviour of these two groups of men was comparable, while others insisted that the traditions of Arab culture would always prevent men from being involved in the daily maintenance of the home.

No, and now men of today are not like men before because men before used to sit and didn't want to do anything, because a woman has to respect her husband, but now the young people, the ones who are marrying now, want to go out with their children, want to help their wives in the house, they want also to bath the children (5)

No, it's not because of the job, but they tolerate a lot from their husbands; I wonder, why tolerate so much? And I told him 'this far and no more', so he has changed, but if I had stayed there [in home country] I don't know if I would have made him change because there is another mentality (4)

Based on the findings of this study, it can be concluded that paid domestic work in Spain has some negative implications for gender equality. Although working mothers have achieved financial independence and even professional success in their jobs, their homes very much resemble those of their grandmothers. Husbands carry on unconcerned, as if the 
fact of being part of a dual earner family had nothing to do with their actual behaviour. Such male lack of awareness of social change is to a great extent made possible, for those who could afford it, by hiring domestic help. This is not to suggest that paid carers or cleaners always have this effect. For it has been argued that such help can facilitate new expressions of solidarity between the sexes, particularly, in terms of closeness and 'quality' of family relationships (Williams 2004). In the case of the UK, for example, Gregson and Lowe (1994) have shown that the use of domestic help among middle-class dual-earner families gave parents the chance to share certain more attractive tasks such as cooking or shopping, while delegating the more demanding ones. In the case of migrant workers it is not yet possible to draw any conclusions although it is clearly shown that the new situations and opportunities made them more conscious of the possibilities that do exist.

\section{Conclusion}

The socio-historical context has facilitated the re-appearance of a significant demand for paid domestic work in Spain, combined with a large supply of migrant women well disposed to engage in this kind of work. Some of the reasons for this are linked to processes of economic restructuring in various areas of the world - which are destroying traditional local economies and often not replacing them - to the segmentation of the labour market and to the late and limited development of the welfare state in Spain. Migrant carers respond to a new situation, particularly that of mothers taking paid work and the increasing need for care of children and the elderly that it generates, for which a general organised solution has not yet been provided by the public authorities. The reconciliation of work and family life is not yet perceived in Spain to be a problem that should involve men and women, the state and the employers, as well as society in general. Dual-earner families are relying on private resources and strategies, one of them being - for those who can afford it - paid domestic help.

Domestic service can be advantageous for women in many senses. Many domestic workers themselves, in spite of their tough lives, achieve financial autonomy, even becoming the main breadwinners in their family, thereby acquiring more status and power. Contact with Spanish society can make them aware of their rights and increases their personal autonomy. It is also advantageous for the working mothers who employ them, as domestic responsibilities thereby cease to be an obstacle to their jobs. They can be as available and committed as men are in their professional life, while knowing that the home is under control. There are, though, other less positive aspects. Care and domestic work goes on being an undervalued activity and remains the responsibility of women - whether domestic workers, or mothers, and grandmothers. This is very clear in the Spanish case where the main actual resources that working mothers can count on have long been other women, who will carry out the task of traditional mothering and homemaking in their absence. The discourses of the informants in this 
study suggest that gendered roles have not changed; only the actors have all of women in this case. Arguably, while it is a big step forward that Spanish society at large accepts the right - increasingly the obligation of mothers to work as one income is not enough to maintain a family - the issue is that this right is not yet supported in practical terms. As shown here, it is taken for granted that it is for the mother who decides to work to make sure that domestic chores and childcare are taken over by somebody else. Men have not yet taken on board that their family responsibilities are no longer limited to being a financial provider because they are no longer the only ones to bring in an income. The state still tends to consider that these matters as low priority - only women's issues. But they are urgent, and cannot wait as children have to be fed, cleaned and taken to school. The re-organisation of care at society level is a complex task that costs money. There are advances but they are happening far too slowly. In the meanwhile, the easiest way to cope, or maybe the only way, is to keep things as they are and look for substitutes who will play the old roles. Domestic service is a sort of prosthesis attached to the Parsonian family, something that makes it go on living even if its original basis, the male breadwinner, is not there any more. From that perspective, what this study reveals is that domestic service may well be delaying the moment when men, the state and society in general, will have to take on board the new reality of dual earner families.

Through domestic workers, care becomes the terrain of market relationships, and like a commodity that can be bought and sold. But the specific characteristics and the actual content of care in terms of where it takes place, of who does it - women - and who hires workers - women too shapes it as a special kind of job. Salaries are low, obligations go beyond what is explicitly agreed, working conditions are loosely defined. The family environment tends to construct paid domestic work in terms of housewives' tasks and roles.

The kind of new inequalities between women are emerging through the employment of care workers for child care and households tasks is an issue to explore in further research. Paid domestic work creates differences and cleavages between women. Spanish working mothers are freed, to some extent, from the obligation to take care of the domestic infrastructure, but it is other women who are assuming those tasks. There is also much to be learnt about how the children who are left behind by their migrant mothers in the global mechanism of care chains are faring. Whereas the traditional boundaries linked care and gender directly, the new boundaries divide women who off-load, and those who take on, the bulk of domestic work. When the division is based on ethnicity, exchanged gazes, stereotypes and prejudices about national and ethnic characteristics all contribute to reinforce boundaries. The kind of new inequalities are appearing in this process is also an issue to go on exploring in further research.

In this study, we found an implicit acknowledgement of the asymmetrical relationship between the support provided by migrants to families and 
children and the scarce help received by them to become members of the Spanish society with full citizenship. On the one hand, as one employer put it: 'Yes, we have them at home, they take care of our children but then we don't really help them to become integrated into the life of Madrid or Spain.' (1). The sentiment was echoed by the immigrant carers. Domestic workers expressed their feelings of not being appreciated or valued for the hard work they do: 'That's what I say, sometimes people are very happy with you but they never acknowledge the work you do.' (3)

\section{ANNEX \\ Methodological notes}

The research was done based on a qualitative approach that allows us to get in touch with the process of construction of collective identities, ethnic relations and concepts of family and care. The results presented are part of a wider research project that seeks to analyse the employer-employee relationship around childcare and its implications on the gendered division of labour. ${ }^{13}$ The analysis presented in this article is based in five discussion groups $^{14}$ that were conducted following the analytical variable of social class for employers and of geographical origin for employees. All women were mothers of children above twelve years old or carers of children above the same age. It was irrelevant if mothers were working outside or inside the house, even though all of them except one were working in a space different form their own houses. For the case of the domestic workers all of them but one have also children of their own, in some cases in the country of origin and in other in the society if destination. The typology of domestic service included was very broad as the participants work or hire domestics as live-in, live-out or on hourly basis. All the groups were conducted in 2002 and were the following: (1) Upper-middle social class Spanish working mothers; (2) Lower-middle class Spanish working mothers; (3) Latin American domestic workers; (4) Eastern European domestic workers; and (5) North African domestic workers.

\section{Acknowledgement}

We want to thank Julia Brannen and Chiara Saraceno for their insightful comments to the paper, as well as Phil Shekleton, the editor and referees for the English revision of the text.

\section{References}

Alonso, L.E. (1998), La Mirada Cualitativa en Sociología, Madrid: Fundamentos.

Anderson, B. (2000), Doing the Dirty Work. The Global Politics of Domestic Labour, London: Zed Books.

Anderson, B. (1997), 'Servants and Slaves: Europe's Domestic Workers', Race $\mathcal{E}$ Class, 39: 1, pp. 37-49.

Ariès, P. (1973), L'enfant et la vie familiale sous l'Ancien Régime, Paris: Éditions du Seuil.

Barrère-Maurisson, A. (2003), Travail, Famille: Le Nouveau Contrat, Paris: Gallimard.
13 The project includes, apart from the discussion groups, 71 in-depth interviews of employers and employees conducted following the same analytical criteria of the groups (social class and geographical origins).

The themes of analysis are much wider and include, among others, the diversification of migration, the new concepts of care and mothering and an in-depth analysis of the dynamics of global care chains and the characteristics of the current domestic work.

14 According to the Spanish School of Qualitative Research, discussion groups are quite different to focus groups. They are used at the first stages of research to widen the meanings of discourse, which will be 'focused' or specified through in-depth surveys (Ibañez 1979; Ortí 2000; Alonso 1998). 
Beauvoir, S. de (1999 [1949]), El Segundo Sexo, Madrid: Cátedra.

Bjornberg, U. (1996), Men's Family Relations, Goteborg, Department of Sociology, Goteborg University.

Bohning, W.R. (1984), Studies of International Migration, London: Macmillan.

Esping-Andersen, G. (1990), The Three Worlds of Welfare Capitalism, Cambridge: Polity.

Esping-Andersen, G. (1999), Social Foundations of Postindustrial Economies, Oxford: Oxford University Press.

Eurostat (2005a), 'Gender Gaps in the Reconciliation between Work and Family Life', Statistics in focus, Population and Social Conditions, 4/2005.

Eurostat (2005b), European Social Statistics. Expenditure and Receipts, Data 1994-2002, Louxebourg.

Gregorio Gil, C. (1998), Migración femenina: su impacto en las relaciones de género, Madrid: Narcea.

Gregory, A. and Windebank, J. (2000), Women's Work in Britain and France. Practice, Theory and Policy, London: Mac Millan Press.

Gregson, N. and Lowe, M. (1994), Servicing the Middle Classes: Class, Gender and Waged Labour in Contemporary Britain, London: Routledge.

Hobson, B., Lewis, J. and Siim, B. (2002), Contested Concepts in Gender and Social Politics, Cheltenham: Edward Elgar.

Hochschild, A.R. (1997), The Time Bind. When Work Becomes Home and Home Becomes Work, Nueva York: Metropolitan Books.

Hochschild, A.R. (2000), 'Global Care Chains and Emotional Superplus Values', in W. Hutton and A. Giddens (eds.), On the Edge: Living with Global Capitalism, London: Jonathan Cape.

Hochschild, A.R. (2003), 'Love and Gold', in B. Ehrenreich and A.R. Hochschild, Global Women, London: Granta Books, pp. 15-30.

Hondagneu-Sotelo (2003), 'Blowups and other unhappy endings' in B. Ehrenreich and A.R. Hochschild, Global Women, London: Granta Books, pp. 55-69.

Ibañez, J. (1979), Más allá de la Sociología, El grupo de discusión: Técnica y crítica, Madrid: Siglo XXI.

Ioé (2001), Mujer, inmigración y trabajo, Madrid: Instituto de Migraciones y Seguridad Social IMSERSO.

Kofman, E., Phizacklea, A., Raghuram, P. and Sales, R. (2000), Gender and International Migration in Europe: Employment, Welfare and Politics, New York, Routledge.

Lan, P. (2003), "Negotiating Social Boundaries and Private Zones: The Micropolitics of Employing Migrant Domestic Workers”, Social Problems, 50: 4, pp. 525-549.

Lan, P. (2003), "Among Women: Migrant Domestics and their Taiwanese Employers across Generations" in B. Ehrenreich and A.R. Hochschild, Global Women, London: Granta Books, pp. 169-189.

Leira, A. (1992), Welfare Status and Working Mothers: The Scandinavian Experience, Cambridge: Cambridge University Press.

Leira, A. (2002), Working Parents and the Welfare State: Family Change and the Policy Reform in Scandinavia, Cambridge, Cambridge University Press.

Lewis, J. (2001), The End of Marriage? Individualism and Intimate Relations, Cheltenham: Edward Elgar.

Longares, M. (2001), Romanticismo, Madrid: Alfaguara.

Malpas, N. (1993), 'Les Européens et la famille’, Eurobarométre, 39.0, Brussels, DG5, European Commission. 
Malpas, N. (1999), 'Européennes- Européens face aux évolutions démographiques. Résultats d'une ênquete d'opinion', Eurobaromètre, 50.1, Brussels, Brussels, DG5, European Commission.

Momsen, J.H. (1999), Gender, Migration and Domestic Service, London: Routledge.

Ortí, A. (2000), "La apertura y el enfoque cualitativo o estructural" en García Ferrando, M.; Ibáñez, J. y Alvira, F. El análisis de la realidad social. Métodos y técnicas de investigación, Madrid: Alianza Editorial.

Otero, L. (1991), La Sección Femenina, Madrid: EDAF.

Parreñas, R. (2003), Servants of Globalization: Women, Migration and Domestic Work, Stanford-California: Stanford University Press.

Scrinzi, F. (2004), 'Ma culture ou je travaille. Les migrants dans les services domestiques en Italie et en France', Cahiers de Cedref, 10, pp. 2-16.

Social Security (Seguridad Social) (2006), Ministerio de Trabajo y Asuntos Sociales, www.seg-social.es/inicio.

Tobío, C., Fernández Cordón, J.A., y Agulló, A. (1998), 'Análisis cuantitativo de las estrategias de compatibilización familia-empleo en España'. informe de resultados de la investigación realizada en el marco del Programa Sectorial de Estudios de las mujeres y el Género Place Nacional de I+D. Departamento de Humanidades, Ciencia Política y Sociología, Universidad Carlos III de Madrid.

Tobío, C. (2001), ‘Working and Mothering: Women’s Strategies in Spain', European Societies, 33, pp.339-371.

Tobío, C. (2005), Madres que trabajan. Dilemas y estrategias, Madrid: Cátedra.

Williams, F. (2004), 'Trends in Women's Employment, Domestic Service and Female Migration: Changing and Competing Patterns of Solidarity' in T. Knijn and A. Komter, Solidarity Between the Sexes and the Generations. Transformations in Europe, Cheltenham: Edward Elgar.

\section{Contributor details}

Constanza Tobío Soler is Professor of Sociology and Vice-Dean at Carlos III University in Madrid. Her main areas of research are gender, the family-employment relationship, care work, and social policy. Her recent publications focus on Spanish working mothers' strategies and the reconciliation of work and family life from a gender perspective. Contact: Constanza Tobío Soler, Departamento de Ciencia Política y Sociología, Despacho 7.38, Universidad Carlos III de Madrid, Calle Madrid 126, Getafe 28903 (Madrid), Spain.

E-mail: ctobio@polsoc.uc3m.es

Magdalena Díaz Gorfinkiel is an Assistant professor in the Department of Sociology at Carlos III University in Madrid and is currently engaged in her thesis project related to immigrant domestic service and family-employment reconciliation. She spent some of her academic and research training at the Universities of Utrecht (Netherlands), Siena (Italy) and Bath (UK). Contact: Magdalena Díaz Gorfinkiel, Despacho 9.0.25, Universidad Carlos III de Madrid, Calle Madrid 126, Getafe 28903 (Madrid), Spain.

E-mail: mdiazg@polsoc.uc3m.es 